\title{
Novel Resistance in Heirloom Tomatoes and Effectiveness of Resistance in Hybrids to Phytophthora infestans US-22, US-23, and US-24 Clonal Lineages
}

\author{
Anna C. Seidl Johnson, Stephen A. Jordan, and Amanda J. Gevens, Department of Plant Pathology, University of Wisconsin- \\ Madison 53706
}

\begin{abstract}
Seidl Johnson, A. C., Jordan, S. A., and Gevens, A. J. 2014. Novel resistance in heirloom tomatoes and effectiveness of resistance in hybrids to Phytophthora infestans US-22, US-23, and US-24 clonal lineages. Plant Dis. 98:761-765.

Late blight, caused by the oomycete Phytophthora infestans, causes serious losses in tomato production worldwide. Application of fungicides is the primary means of management but cultivar resistance, primarily through $P h$ resistance genes from Solanum pimpinellifolium, can provide a cost-effective and environmentally sound approach to an overall disease management program. Due to highly adaptable pathogen populations, cultivar resistance against late blight is often short lived and continual assessment of disease response to new pathogen types is necessary. We evaluated the disease response of 11 tomato cultivars to one isolate from each of three clonal lineages (US-22, US23, and US-24) of $P$. infestans novel to the United States to determine the efficacy of currently deployed $P h$ genes in hybrid cultivars and the validity of claims of resistance in heirloom cultivars. Lesion length and pathogen growth were reduced on tomato genotypes 'Plum Regal' ( $P h$ -

3) and 'Legend' ( $P h-2)$ compared with the susceptible control 'Brandywine Red' following inoculation with one isolate (US-23) but were not significantly different from the control with an isolate of US-22. 'Mountain Magic' ( $P h-2$ and $P h-3)$ and three heirloom cultivars ('Wapsipinicon Peach', 'Matt's Wild Cherry,' and 'Pruden's Purple') had reduced lesion length and pathogen growth to all three isolates. Although the genetics of resistance are not fully understood for many of these, the heirloom cultivars may be useful for future tomato late blight breeding efforts. All of the cultivars investigated in this work are currently available and use of cultivars exhibiting reduced disease development may limit losses to late blight and reduce reliance on fungicides. Resistant cultivars also limit the production of inoculum, reducing overall late blight risk and spread in tomato and potato crops.
\end{abstract}

Phytophthora infestans (Mont.) de Bary causes late blight, a serious disease in tomato (Solanum lycopersium L.) production worldwide. In the United States, late blight is considered the eighth most important disease of tomato production based on the potential for economic loss (10). Tomato late blight can also affect potato production, where worldwide potato late blight losses are estimated at $\$ 6.7$ billion annually (31). Lesions produced on leaves and stems can cause a plant to defoliate and collapse while lesions produced on ripe or unripe fruit result in unmarketable produce and contribute directly to economic loss (36). P. infestans is a heterothallic oomycete pathogen with a short generation time of 4 to 5 days and, under cool, wet, humid conditions, the asexual sporangia can quickly spread throughout a field and into surrounding fields, rapidly devastating susceptible and unprotected crops (36).

Since the time of its discovery as the biological cause of the Irish potato famine in the late $1840 \mathrm{~s}, P$. infestans had largely been considered a potato pathogen (26). However, isolates have been identified that infect both potato and tomato (27). In the United States, the late blight population has limited diversity due to lack of sexual recombination and has been categorized into clonal lineages, or asexual descendants of a single genotype (17). In the United States, US- 8 was one of the first widespread clonal lineages that required vigilant management on both potato and tomato (27). Since then, several lineages have been identified that readily infect tomato and potato (27) as well as lineages that are primarily pathogenic on tomato and will not cause disease on potato under field conditions (32). Thus, it is critically important to understand which lineages are present within a given region for optimized management of late blight for both tomato and potato.

Corresponding author: A. Gevens, E-mail: gevens@wisc.edu

Accepted for publication 1 January 2014.

http://dx.doi.org/10.1094/PDIS-06-13-0674-RE

(C) 2014 The American Phytopathological Society
Management of late blight on tomato requires an integrated approach of cultural and chemical strategies. In the United States, asexual reproduction of $P$. infestans by ephemeral sporangia is the primary means of reproduction, because the A1 and A2 mating types of this heterothallic pathogen have historically not been in close proximity to establish a persistent soil oospore population $(27,36,53)$. Therefore, in northern regions with freezing winters, the pathogen can, in theory, be eradicated between growing seasons, unless viable infected plant tissues are harbored in warm compost piles or greenhouses, or buried in fields or potato cull piles (3). Removing these overwintering environments can impact pathogen overwintering potential and reduce late blight risk in a region the following season through the reduction of primary inoculum. However, the pathogen can be present in seed potato tubers or tomato transplants, and sporangia can be aerially transported from other regions; therefore, late blight management is often still necessary $(35,51)$. During the growing season, fungicides are commonly used to manage late blight as well as other foliar diseases, often in conjunction with disease forecasting models that optimize timing of applications based on environmental conditions favorable to $P$. infestans $(39,56)$. Fungicides are available with contact, protectant, translaminar systemic, and truly systemic activity against tomato late blight (8). All fungicides are most effective when applied before late blight infection has occurred. Many clonal lineages (i.e., US-8) have been identified that are insensitive to the active ingredient mefenoxam, an oomycetespecific fungicide, rendering it useless against certain pathogen populations $(27,54)$. The use of fungicides adds chemical and labor costs to production $(30,44)$; in addition, choices for effective fungicides are limited in organic production systems.

To enhance integrated late blight management within the growing season and reduce reliance on chemical control, host resistance has been investigated for tomato late blight management. Tomato late blight resistance breeding began in 1946 with the screening of close relatives of tomato for resistance (50). Since that time, a few resistance genes, designated $P h-1, P h-2$, and $P h-3$, were discovered in S. pimpinellifolium and mapped to regions of the tomato 
chromosomes $(2,7,15,19,34,43,46)$. Most recently, further screening of this Solanum sp. has identified two genes tentatively named $P h-5-1$ and $P h-5-2$ (46). The first two $P h$ genes were bred into commercial tomato cultivars and were effective for some time but new compatible races of $P$. infestans emerged $(15,28,46)$. Tomato cultivars containing $P h-3$ were subsequently released and, again, isolates of $P$. infestans developed compatibility to this individual resistance gene as well $(6,15,20,38,46)$.

Throughout its history, $P$. infestans has been infamous for its plasticity and ability to develop virulence toward the $P h$ resistance genes (16). The history of resistance breeding in potato is longer than that in tomato, and $P$. infestans isolates quickly adapted to all 11 potato resistance genes identified $(4,28)$. In both potato and tomato, there is potential that broad-spectrum resistance or quantitative trait loci-based field resistance may have targets of reduced specificity and, thus, may be less easily overcome than single, dominant resistance genes $(1,15,46)$. However, the durability of these kinds of late blight resistance has yet to be rigorously tested. Mutations in the asexual $P$. infestans population have largely been responsible for overcoming resistance genes deployed thus far; isolates within a single clonal lineage can vary in virulence (28). With the introduction of several clonal lineages to an area, the potential for overcoming multiple resistance genes is increased.

In the United States, genetic diversity in the P. infestans population was thought to be limited up until the late 1980s, with US-1 as the only clonal lineage found in northern North America (27). Since that time, many new clonal lineages have been discovered and assigned a US-number designation $(27,53)$. In the purported absence of sexual recombination in the United States, it was hypothesized that these lineages have been introduced from Mexico, where sexual recombination is common $(25,29)$. With the arrival of the US- 8 clonal lineage, the US- 1 and other lineages were displaced and US-8 remained the most common lineage in many parts of the United States for many years (27). During 2009, the US-22 clonal lineage quickly became widespread throughout the eastern and midwestern United States, due largely to the distribution of late blight-infected tomato transplants $(18,32,51)$. In subsequent years, US-23 and US-24 were also identified, and the previously predominant US-8 clonal lineage was nearly displaced $(9,37,53)$.

The arrival of new lineages that were highly aggressive on tomato in the field brought into question the effectiveness of resistance toward $P$. infestans in tomato cultivars. Based on surveys of commercial fields in 2009, some cultivars with no known $P h$ resistance genes appeared to have less severe symptoms under the high natural disease pressure than others. The objectives of this work were to (i) evaluate heirloom tomato cultivars for potentially novel sources of late blight resistance against the new clonal lineages of $P$. infestans US-22, US-23, and US-24 and (ii) evaluate the effectiveness of currently deployed tomato $P h$ resistance genes toward isolates of these lineages. To accomplish this, we evaluated the disease and pathogen response of several heirloom tomato cultivars with potential late blight resistance and commercially available hybrid tomato cultivars containing the $P h$ resistance genes after inoculation with one isolate from each of the US-22, US-23, and US-24 P. infestans clonal lineages on detached leaves.

\section{Materials and Methods}

Three isolates of $P$. infestans-US-22 (Pi7-09a), US-23 (Pi1610a), and US-24 (Pi21-10a) - were used in this study. These were collected from symptomatic plant tissues from Wisconsin (53): Pi7-09a (A2, mefenoxam sensitive) was isolated from tomato fruit, Pi16-10 (A1, mefenoxam sensitive) from tomato foliage, and Pi2110a (A1, mefenoxam intermediately sensitive) from potato foliage (53). We maintained isolates in hemp seed long-term storage vials (40) in the Potato and Vegetable Pathology Laboratory at the University of Wisconsin-Madison.

Ten tomato cultivars with putative resistance to late blight and one susceptible control were used for the experiment. The cultivars were chosen based on one or more of the following criteria: (i) documented presence of $P h$ resistance genes, (ii) data from previous field studies indicating resistance to previous $P$. infestans populations (12,33), (iii) claims by seed companies of late blight resistance, or (iv) data from surveys of commercial fields in 2009 that exhibited reduced late blight severity (Table 1). Seed was purchased from Johnny's Selected Seeds ('Pruden's Purple'), Totally Tomatoes ('Legend', 'Roma', 'Green Zebra', 'Wapsipinicon Peach', and 'Juliet'), Seedway LLC ('Mountain Magic' and 'Plum Regal') (20,21), and Reimer Seeds ('Matt's Wild Cherry', 'Brandywine Red', and 'Slava') and all tomato plants were grown in a growth chamber at $28^{\circ} \mathrm{C}$ with a 14 -h photoperiod.

Detached leaf assays were used to evaluate resistance $(41,59)$. For each cultivar, six fully expanded leaflets from 4- to 5-week-old tomato plants were detached using a sharp razor blade and immediately placed adaxial surface up in three 9 -cm-diameter petri dishes directly on a thin layer of water agar, two leaves per plate. To prepare inoculum, 2- to 4-week-old actively growing cultures of each of the three isolates of $P$. infestans were flooded with sterile distilled water and brushed gently to dislodge sporangia. The resulting suspensions were transferred to sterile plastic $50-\mathrm{ml}$ centrifuge tubes and the concentrations quantified using a hemacytometer. Each suspension was adjusted to 50,000 sporangia/ml by adding sterile distilled water. Five leaflets in each six-leaflet culti-

Table 1. Lesion and pathogen growth responses of tomato cultivars evaluated for late blight resistance against isolates of the US-22, US-23, and US-24 clonal lineages of Phytophthora infestans $\mathrm{s}^{\mathrm{v}}$

\begin{tabular}{|c|c|c|c|c|c|c|c|}
\hline \multirow[b]{2}{*}{ Cultivar $^{\mathrm{y}}$} & \multirow[b]{2}{*}{ Selection parameter $^{\mathrm{z}}$} & \multicolumn{3}{|c|}{ AULEC ${ }^{w}$} & \multicolumn{3}{|c|}{ AUPGC $^{x}$} \\
\hline & & US-22 & US-23 & US-24 & US-22 & US-23 & US-24 \\
\hline Wapsipinicon & Field observation & $80.5 \mathrm{a}$ & $116.2 \mathrm{a}$ & $12.6 \mathrm{a}$ & $72.5 \mathrm{a}$ & $155.0 \mathrm{bcd}$ & $0.0 \mathrm{a}$ \\
\hline Mountain Magic & $P h-2$ and $P h-3$ & $96.1 \mathrm{ab}$ & $67.1 \mathrm{a}$ & $49.8 \mathrm{ab}$ & $73.8 \mathrm{a}$ & $22.5 \mathrm{a}$ & $27.5 \mathrm{ab}$ \\
\hline Matt's Wild Cherry & Seed company & $87.6 \mathrm{ab}$ & $128.7 \mathrm{ab}$ & $22.2 \mathrm{ab}$ & $70.0 \mathrm{a}$ & $118.8 \mathrm{ab}$ & $10.0 \mathrm{a}$ \\
\hline Pruden's Purple & Other research & $177.0 \mathrm{abc}$ & $153.0 \mathrm{ab}$ & $48.4 \mathrm{ab}$ & $180.0 \mathrm{ab}$ & $136.3 \mathrm{abc}$ & $20.0 \mathrm{ab}$ \\
\hline Legend & $P h-2$ & $213.6 \mathrm{~cd}$ & $161.5 \mathrm{abc}$ & $79.2 \mathrm{abc}$ & $271.3 \mathrm{bc}$ & 201 bcde & $96.3 \mathrm{abcd}$ \\
\hline Plum Regal & $P h-3$ & 243.9 cde & $137.5 \mathrm{ab}$ & $110.6 \mathrm{bc}$ & $206.3 \mathrm{~b}$ & $147.5 \mathrm{bcd}$ & $106.3 \mathrm{abcd}$ \\
\hline Juliet & Seed company & $180.0 \mathrm{bc}$ & $214.0 \mathrm{bcd}$ & $108.2 \mathrm{abc}$ & $228.8 \mathrm{~b}$ & $246.3 \mathrm{cdef}$ & $150.0 \mathrm{~cd}$ \\
\hline Roma & Field observation & $257.3 \mathrm{cde}$ & $251.8 \mathrm{~cd}$ & $81.7 \mathrm{abc}$ & $272.5 \mathrm{bc}$ & $261.3 \mathrm{def}$ & $48.8 \mathrm{abc}$ \\
\hline Slava & Other research & 249.3 cde & $277.1 \mathrm{~d}$ & $100.5 \mathrm{abc}$ & $271.3 \mathrm{bc}$ & 293.8 ef & $136.3 \mathrm{bcd}$ \\
\hline Green Zebra & Other research & $321.0 \mathrm{e}$ & $295.5 \mathrm{~d}$ & $114.9 \mathrm{bc}$ & $365.0 \mathrm{c}$ & $322.5 \mathrm{f}$ & $152.5 \mathrm{~cd}$ \\
\hline Brandywine Red & Susceptible control & $293.7 \mathrm{de}$ & $304.1 \mathrm{~d}$ & $160.9 \mathrm{c}$ & $268.8 \mathrm{bc}$ & 285.0 ef & $205.0 \mathrm{~d}$ \\
\hline
\end{tabular}

v Values in each column followed by the same letter are not significantly different based on Tukey's test at the $95 \%$ level of confidence.

${ }^{w}$ Lesion length was measured at $0,5,7$, and 9 days after inoculation and used to calculate area under the lesion expansion curve (AULEC)

${ }^{x}$ Percent leaf coverage of pathogen growth was determined at $0,5,7$, and 9 days after inoculation and used to calculate area under the pathogen growth curve (AUPGC).

y Mountain Magic, Plum Regal, and Juliet are hybrids. Legend was bred to contain $P h-2$ resistance but is open pollinated and, therefore, is considered an heirloom by some. The remaining cultivars are heirlooms.

${ }^{\mathrm{z}}$ Cultivars were selected based on anecdotal field observations from 2009, claims by seed companies of late blight resistance, field trials using other $P$. infestans clonal lineages (12,33), or the presence of resistance genes $P h-2$ or $P h-3$. 
var set were inoculated with $10-\mu$ d droplets of a suspension of a single clonal lineage. The sixth leaflet was mock inoculated with a $10-\mu l$ droplet of sterile distilled water as a control. Plates were placed in plastic boxes with nonsealing lids and incubated at $20^{\circ} \mathrm{C}$ in the dark. Lesions were defined as either visible sporulation or necrotic or chlorotic diseased tissue and the lesion length was measured in millimeters along the midvein with a ruler at $0,5,7$, and 9 days post inoculation (dpi). To avoid bias, leaflets of approximately the same size were chosen for each cultivar and ratings ceased at 9 dpi to avoid measuring lesions that could extend beyond the length of the smallest leaflets. Aerial pathogen growth (mycelia, sporangia, and sporangiophores) was estimated and assigned to the categories of $0,25,50,75$, or $100 \%$ coverage of the leaflet surface at each of the same time points. The experiment was performed twice and results were pooled for analysis. Area under the lesion expansion curve (AULEC) and area under the pathogen growth curve (AUPGC) were calculated for each cultivar-clonal lineage combination using the area under the disease progress curve function in the Agricolae package for R (11). A two-way analysis of variance was performed on the resulting values using SigmaPlot (Systat Software) and significant differences between cultivars and clonal lineages were determined using Tukey's tests at the $95 \%$ level of confidence. There are many uses of the term resistance. In this study, the type of resistance we describe is not immunity; rather, it is defined by comparison with plant controls that express more disease (susceptible).

\section{Results}

Results from our two experiments were similar, with no detection of disease or pathogen growth on our mock-inoculated control leaflets. No cultivar gave an immune disease response typical for a gene-for-gene or resistance-gene relationship, nor did we detect latency of plant disease responses to any of the isolates of the three clonal lineages of $P$. infestans at 5, 7, or 9 dpi. Rather, partial resistance best typified the reduced disease and pathogen growth responses observed.

Late blight lesions were apparent at 5 dpi for all tomato cultivars and ranged across cultivars from the most aggressive isolate of clonal lineage US-22, with lengths of 7.9 to $40.7 \mathrm{~mm}$, to the least aggressive isolate of lineage US-24, with lengths of 1.8 to 17.7 $\mathrm{mm}$. Lesions increased in length at each subsequent rating to $9 \mathrm{dpi}$. Percentage of the leaflets exhibiting pathogen growth was low or not present at $5 \mathrm{dpi}$ for nearly all of the cultivars, with ranges of 2.5 to $35 \%$ for the isolates of lineage US-22, 0 to $30 \%$ for US-23, and 0 to $25 \%$ for US-24. Visible pathogen growth of mycelia, sporangiophores, and sporangia increased in percentage of area covered at each subsequent rating to 9 dpi.

Overall, the isolate of the US-24 clonal lineage of $P$. infestans produced the smallest AULEC values across all of the tomato cultivars inoculated (mean $=20.6)$ compared with isolates of US-22 $($ mean $=50.2, P<0.001)$ and US-23 (mean $=49.3, P<0.001)$. Similarly, AUPGC values were less when inoculated with an isolate of US-24 (mean $=86.6)$ than with US-22 (mean $=207.3, P<$ $0.001)$ or US-23 (mean $=199.1, P<0.001)$. Individual cultivars inoculated with the isolate of US-24 had AULEC and AUPGC values significantly less than cultivars inoculated with isolates of US-22 and US-23 on almost all of the cultivars (Table 1).

Mountain Magic, Matt's Wild Cherry, Wapsipinicon Peach, and Pruden's Purple had significantly lower AULEC and AUPGC values following inoculation with isolates of $P$. infestans of US-22 and US-23 lineages (Table 1). Plum Regal and Legend had low AULEC values when inoculated with the isolate of US-23; however, these were higher and not significantly different than the most susceptible cultivars (Table 1). Juliet, Roma, Slava, Green Zebra, and Brandywine Red all resulted in high AULEC and AUPGC values (Table 1).

The cultivars containing $P h$ resistance genes demonstrated varying levels of resistance when inoculated with each lineage but were among the cultivars with the lowest AULEC and AUPGC values of all tested. Plum Regal $(P h-3)$ had significantly larger lesions when inoculated with US-22 compared with US-23 $(P=0.001)$ and US$24(P<0.001)$ (Table 1$)$. For US-22, the AULEC on Plum Regal was not significantly different than the most susceptible cultivar $(P$ $=0.277$ ); however, AUPGC for US-22 on Plum Regal was significantly less than the cultivar with the greatest AUPGC $(P<0.001)$, although still greater than the cultivar with the least AUPGC $(P=$ 1.0) (Table 1). For US-23 inoculated onto Plum Regal, AULEC was statistically similar to the most resistant cultivar $(P=0.416)$ and AUPGC was statistically less than the most susceptible $(P<$ $0.001)$ (Table 1). On Legend $(P h-2)$, inoculation with isolates of US-22 and US-23 resulted in a similar disease response, with both AULEC and AUPGC not significantly different between lineages $(P=0.197$ and 0.140 , respectively; Table 1$)$. However, Mountain Magic $(P h-2+P h-3)$ showed a high level of resistance when inoculated with individual isolates of each of US-22, US-23, and US-24 clonal lineages; AULEC and AUPGC values were not significantly different between lineages on this cultivar (Table 1).

\section{Discussion}

Knowledge of the effectiveness of resistance genes currently deployed in readily available tomato cultivars can help growers and home gardeners manage late blight with less reliance on fungicides and reduce overall inoculum. Under controlled experimental conditions, several commercially available tomato cultivars expressed reduced symptoms of late blight and pathogen growth following inoculation with individual isolates of $P$. infestans clonal lineages US-22, US-23, and US-24, as shown by reduced lesion size and overall colonization of detached tomato leaves. Detached leaves provide a useful assay as predictors of intact plant resistance $(41,59)$. In addition to cultivars that have been bred for $P h$ resistance, we identified three heirloom cultivars with no known resistance that resulted in reduced disease responses to the new lineages. The currently uncharacterized resistance in Matt's Wild Cherry, Wapsipinicon Peach, and Pruden's Purple may be useful in future breeding efforts.

Matt's Wild Cherry is an heirloom cultivar that had low AULEC and AUPGC values when challenged with individual isolates of the $P$. infestans US-22, US-23, and US-24 clonal lineages. This cultivar is a variety of tomato known as $S$. lycopersium var. cerasiforme, although there is disagreement among taxonomists on the degree of relatedness of this variety to $S$. piminellifolium or the common garden tomato $S$. lycopersicum $(48,49)$. The seed for the cultivar was originally collected near Hildalgo, Mexico, which is only $150 \mathrm{~km}$ from the Toluca Valley, a center of diversity for $P$. infestans. As such, the population from which this cultivar originated was very likely subjected to selection pressure for late blight resistance, possibly explaining the resistance response. The underlying genetic cause for the resistance to these isolates is unknown and, to our knowledge, no late blight resistance has ever been deliberately bred into this cultivar.

The history of Wapsipinicon Peach has not been carefully documented but the cultivar is suspected of being synonymous with 'White Peach' which may have a cross with S. pimpinellifolium, the species from which current $P h$ resistance genes have been introgressed, in its background (14,52). Further molecular analysis could conclusively determine the genetics and resolve the resistance character. However, the significantly reduced lesion and pathogen growth response of Wapsipinicon Peach when compared with Legend and Plum Regal suggests that the resistance is not likely from $P h-2$ or $P h-3$ alone.

Pruden's Purple is an heirloom tomato cultivar with little known of its history. AULEC and AUPGC values for this cultivar were low and statistically equivalent to Wapsipinicon Peach, Matt's Wild Cherry, and Mountain Magic. The fruit of Pruden's Purple are larger than that of the aforementioned cultivars, making it potentially more useful to producers or gardeners desiring late blight resistance and larger fruit size. As with Wapsipinicon Peach and Matt's Wild Cherry, the resistance of Pruden's Purple was consistently observed for the individual isolates of the three clonal lineages tested, indicating potential broad-spectrum resistance. 
The genetic backgrounds of the tomato cultivars containing $P h$ resistance genes may explain the unexpected results obtained when these were inoculated with the isolate of $P$. infestans clonal lineage US-22. Legend, an older cultivar released in 2001 containing $P h-2$, and Plum Regal, a newer cultivar released in 2010 containing heterozygous $P h-3$, were both not significantly more resistant than the most susceptible cultivar when challenged with the US-22 clonal lineage. However, when $P h-2$ and $P h-3$ were combined in Mountain Magic (heterozygous), a high level of resistance resulted. The sources of $P h-2$ for Legend and Mountain Magic are different but the genes have been determined to be allelic $(5,20,21,45)$. The $P h-3$ resistance in both Mountain Magic and Plum Regal originates from the same accession of $S$. pimpinellifolium, L3707 $(20,21,45)$. However, the Ph-3 late blight resistance in this accession should be attributed to two genes, one partially dominant gene and a second, independent dominant gene that is epistatic to the first and necessary for expression of resistance (34). One or the other of these genes may not be expressed as strongly in Plum Regal as in Mountain Magic, simply as an artifact of the breeding process, perhaps explaining why two apparently ineffective resistance genes appear to become effective when combined. Alternatively, combining defeated resistance genes can sometimes lead to effective resistance; this residual effect has been shown in potato $(58)$ and other crops $(13,42,47)$. It is speculated that the defeated genes still contribute a low level of resistance and, when these genes are combined, a more complete resistance results $(1,58)$. Neither Plum Regal nor Legend showed a very high level of resistance when challenged with US-22, suggesting that the Ph-2 and $P h-3$ resistance genes had been defeated by this clonal lineage. However, Mountain Magic was quite resistant, supporting the hypothesis of a residual effect of defeated resistance genes in this cultivar.

The different responses of the clonal lineages underscore the importance of testing new clonal lineages and multiple isolates of $P$. infestans for aggressiveness. That the representative isolate of US24 was only weakly aggressive on tomato foliage under controlled and disease-favorable environmental conditions and resulted in significantly reduced lesion length and pathogen growth at 5 dpi when compared with the other lineages indicates that tomato growers may not need to be as rigorous in applying protective fungicides if US-24 is the only prevalent lineage in a region. The reduced aggressiveness of US-24 on tomato has been previously documented based on tests of single cultivars $(9,53)$; our results extend this finding to 11 additional cultivars. US-22 and US-23 both appear to have similar aggressiveness on the range of tomato cultivars tested. An exception was Plum Regal, which was less resistant to US-22 than US-23. Knowledge that Plum Regal has resistance against prominent clonal lineages of $P$. infestans may be immediately useful to tomato growers. However, field reports from 2013 indicated that Plum Regal fruit, unlike the foliage, were susceptible to late blight caused by recently characterized $P$. infestans clonal lineages, including US-23 (B. Gugino, personal communication).

Within a clonal lineage, aggressiveness or virulence patterns can vary among individual isolates; however, the majority of the variation in $P$. infestans populations in the United States is between clonal lineages $(28,41)$. This is particularly true in newer clonal lineages that have not yet been subjected to years of selection pressure (28). The US-22, US-23, and US-24 clonal lineages in the United States have only recently been discovered $(9,22-24,32)$; therefore, our testing of a single isolate from each is likely representative of the predominant pathogen populations in the United States at this time. However, continued testing of additional isolates of old and new clonal lineages of P. infestans as they are identified will keep our knowledge of the virulence of the population current and will be useful to breeders and growers.

Cultivar resistance to late blight, even if only partial, can contribute to integrated late blight management in both organic and conventional tomato production. Late blight is a "community disease" easily spread from the thousands of sporangia produced within each lesion and carried on air currents $(36,57)$. Fungicide applications are not usually recommended or feasible for home gardeners, yet these small plots can serve as a source of late blight inoculum for larger-scale tomato or potato production (51), resulting in significant increases in overall commercial fungicide usage. The use of resistant cultivars should contribute to an overall reduced level of inoculum in a region, lessening the risk of late blight and requiring fewer fungicide applications and associated input costs (55). The heirloom and hybrid tomato cultivars identified in this study with reduced disease and pathogen growth may be useful in current late blight control programs, especially in organic systems where effective fungicide options are limited, and may provide novel sources of resistance for future breeding efforts.

\section{Acknowledgments}

This work was supported, in part, by Hatch Formula Funds granted to A. J. Gevens at the University of Wisconsin-Madison and a Wisconsin Potato Industry Board-Wisconsin Distinguished Graduate Fellowship to Anna C. Seidl Johnson. We thank the commercial farms that allowed us access to their tomato fields for late blight observations, and K. Cleveland and A. Mitchell for technical assistance in the University of Wisconsin Potato and Vegetable Pathology Laboratory.

\section{Literature Cited}

1. Adillah Tan, M. Y., Hutten, R. C. B., Celis, C., Park, T.-H., Niks, R. E., Visser, R. G. F., and van Eck, H. J. 2008. The $R_{P i-m c d l}$ locus from Solanum microdontum involved in resistance to Phytophthora infestans, causing a delay in infection, maps on potato chromosome 4 in a cluster of NBS-LRR genes. Mol. Plant-Microbe Interact. 21:909-918.

2. AVRDC. 1994. Pages 201-203 in: 1993 Progress Report. Asian Vegetable Research and Development Center, Shanhua, Tainan, Taiwan.

3. Bonde, R., and Schultz, E. S. 1943. Potato cull piles as a source of late blight infection. Am. Potato J. 20:112-118.

4. Bradshaw, J. E., Bryan, G. J., Lees, A. K., McLean, K., and SolomonBlackburn, R. M. 2006. Mapping the R10 and R11 genes for resistance to late blight (Phytophthora infestans) present in the potato (Solanum tuberosum) R-gene differentials of Black. Theor. Appl. Genet. 112:744-751.

5. Brusca, J. P. 2003. Inheritance of tomato late blight resistance from 'Richter's Wild Tomato' and evaluation of late blight resistance gene combinations in adapted fresh marked tomato backgrounds. Dep. Hortic. Sci. North Carolina State Univ. Raleigh.

6. Chen, C.-H., Sheu, Z.-M., and Wang, T.-C. 2008. Host specificity and tomato-related race composition of Phytophthora infestans isolates in Taiwan during 2004 and 2005. Plant Dis. 92:751-755.

7. Chunwongse, J., Chunwongse, C., Black, L., and Hanson, P. 2002. Molecular mapping of the $P h-3$ gene for late blight resistance in tomato. J. Hortic. Sci. Biotechnol. 77:281-286.

8. Cohen, Y., Reuveni, M., and Eyal, H. 1979. The systemic antifungal activity of Ridomil against Phytophthora infestans on tomato plants. Phytopathology 69:645-649.

9. Danies, G., Small, I. M., Myers, K., Childers, R. A., and Fry, W. E. 2013. Phenotypic characterization of recent clonal lineages of Phytophthora in festans in the United States. Plant Dis. 97:873-881.

10. Davis, R. M., Hamilton, G., Lanini, W. T., Spreen, T. H., and Osteen, C. 1998. The importance of pesticides and other pest management practices in U.S. tomato production. U. S. Dep. Agric. Natl. Agric. Pestic. Impact Assessment Program Document No. 1-CA-98.

11. de Mendiburu, F. 2009. Agricolae: Statistical Procedures for Agricultural Research. R package version 1.0-7. http://cran.r-project.org/web/packages/ agricolae/index.html

12. Dillon, M., Navazio, J., Dean, K., and Rosenmyer, M. 2005. Public breeding for organic agriculture-screening for horizontal resistance to late blight in tomato. Pages 1-12 in: Organic Farming Research Foundation Final Project Report, Santa Cruz, CA.

13. Durel, C. E., Parisi, L., Laurens, F., van de Weg, W. E., Liebhard, R., and Jourjon, M. F. 2003. Genetic dissection of partial resistance to race 6 of Venturia inaequalis in apple. Genome 46:224-234.

14. East, E. M. 1915. E.S. CARMAN: One of the greatest of American plant breeders-His work too little appreciated-Success with potatoes most noteworthy-His activity as a journalist. J. Hered. 6:65-67.

15. Foolad, M. R., Merk, H. L., and Ashrafi, H. 2008. Genetics, genomics and breeding of late blight and early blight resistance in tomato. Crit. Rev. Plant Sci. 27:75-107.

16. Fry, W. E. 2008. Phytophthora infestans: the plant (and $R$ gene) destroyer. Mol. Plant Pathol. 9:385-402.

17. Fry, W. E., and Goodwin, S. B. 1997. Re-emergence of potato and tomato late blight in the United States. Plant Dis. 81:1349-1357.

18. Fry, W. E., McGrath, M. T., Seaman, A., Zitter, T. A., McLeod, A., Danies, G., Small, I. M., Myers, K., Everts, K., Gevens, A. J., Gugino, B. K., Johnson, S. B., Judelson, H. S., Ristaino, J., Roberts, P. D., Secor, G., Seebold K. J., Snover-Clift, K., Wyenandt, A., Grünwald, N. J., and Smart, C. D. 
2012. The 2009 late blight pandemic in the eastern United States-causes and results. Plant Dis. 97:296-306.

19. Gallegly, M. E., and Marvel, M. E. 1955. Inheritance of resistance to tomato race-0 of Phytophthora infestans. Phytopathology 45:103-109.

20. Gardner, R. G., and Panthee, D. R. 2010. 'Plum Regal' fresh-market plum tomato hybrid and its parents, NC 25P and NC 30P. HortScience 45:824825 .

21. Gardner, R. G., and Panthee, D. R. 2012. 'Mountain Magic': An early blight and late blight-resistant specialty type $F_{1}$ hybrid tomato. HortScience 47:299-300.

22. Gevens, A. J., and Seidl, A. C. 2013. First report of late blight caused by Phytophthora infestans clonal lineage US-23 on tomato and potato in Wisconsin, United States. Plant Dis. 97:839.

23. Gevens, A. J., and Seidl, A. C. 2013. First report of late blight caused by Phytophthora infestans clonal lineage US-24 on potato (Solanum tuberosum) in Wisconsin. Plant Dis. 97:152.

24. Gevens, A. J., and Seidl, A. C. 2013. First report of late blight caused by Phytophthora infestans clonal lineage US-22 on tomato and potato in Wisconsin. Plant Dis. 97:432.

25. Goodwin, S. B., Cohen, B. A., Deahl, K. L., and Fry, W. E. 1994. Migration from northern Mexico as the probable cause of recent genetic changes in the populations of Phytophthora infestans in the United States and Canada. Phytopathology 84:553-558.

26. Goodwin, S. B., Cohen, B. A., and Fry, W. E. 1994. Panglobal distribution of a single clonal lineage of the Irish potato famine fungus. Proc. Natl. Acad. Sci. USA 91:11591-11595.

27. Goodwin, S. B., Smart, C. D., Sandrock, R. W., Deahl, K. L., Punja, Z. K., and Fry, W. E. 1998. Genetic change within populations of Phytophthora infestans in the United States and Canada during 1994 to 1996: role of migration and recombination. Phytopathology 88:939-949.

28. Goodwin, S. B., Sujkowski, L. S., and Fry, W. E. 1995. Rapid evolution of pathogenicity within clonal lineages of the potato late blight disease fungus. Phytopathology 85:669-676.

29. Grünwald, N. J., and Flier, W. G. 2005. The biology of Phytophthora infestans at it center of origin. Annu. Rev. Phytopathol. 43:171-190.

30. Guenthner, J. F., Michael, K. C., and Nolte, P. 2001. The economic impact of potato late blight on US growers. Potato Res. 44:121-125.

31. Haverkort, A. J., Boonekamp, P. M., Hutten, R., Jacobsen, E., Lotz, L. A. P., Kessel, G. J. T., Visser, R. G. F., and van der Vossen, E. A. G. 2008. Societal costs of late blight in potato and prospects of durable resistance through cisgenic modification. Potato Res. 51:47-57.

32. Hu, C.-H., Perez, F. G., Donahoo, R. S., McLeod, A., Myers, K., Ivors, K., Secor, G., Roberts, P. D., Deahl, K. L., Fry, W. E., and Ristaino, J. B. 2012. Recent genotypes of Phytophthora infestans in the eastern United States reveal clonal populations and reappearance of mefenoxam sensitivity. Plant Dis. 96:1323-1330.

33. Inglis, D., Gundersen, B., Derie, M., and Vestey, E. 2001. Evaluation of tomato germplasm for resistance to late blight. Biol. Cultural Tests Control Plant Dis. Rep. No. 16:PT77.

34. Irzhansky, I., and Cohen, Y. 2006. Inheritance of resistance against Phytophthora infestans in Lycopersicon pimpinellifolium L3707. Euphytica 149:309-316.

35. Johnson, D. A., and Cummings, T. F. 2013. A plant stem inoculation assay for assessing transmission of Phytophthora infestans from potato seed tubers to emerged shoots. Plant Dis. 97:183-188.

36. Jones, J. B., Jones, J. P., Stall, R. E., and Zitter, T. A., eds. 1991. Compendium of Tomato Diseases. American Phytopathological Society, St. Paul, $\mathrm{MN}$.

37. Kalischuk, M., Al-Mughrabi, K. I., Peters, R. D., Howard, R. J., Platt, H. W., and Kawchuk, L. M. 2012. Genetic composition of Phytophthora infestans in Canada reveals migration and increased diversity. Plant Dis. 96:1729-1735

38. Kim, M.-J., and Mutscher, M. 2005. Transfer to processing tomato and characterization of late blight resistance derived from Solanum pimpinellifolium L. L3708. J. Am. Soc. Hortic. Sci. 130:877-884.

39. Krause, R. A., Massie, L. B., and Hyre, R. A. 1975. BLITECAST, a computerized forecast of potato late blight. Plant Dis. Rep. 59:95-98.

40. Lamour, K. H., and Hausbeck, M. K. 2001. Investigating the spaciotemporal genetic structure of Phytophthora capsici in Michigan. Phytopathology 91:973-980.

41. Legard, D. E., Lee, T. Y., and Fry, W. E. 1995. Pathogenic specialization in Phytophthora infestans: aggressiveness on tomato. Phytopathology 85:1356-1361.

42. Li, Z. K., Luo, L. J., Mei, H. W., Paterson, A. H., Zhao, X. Z., Zhong, D. B., Wang, Y. P., Yu, X. Q., Zhu, L., R., T., Stansel, J. W., and Ying, C. S. 1999. A "defeated" rice resistance gene acts as a QTL against a virulent strain of Xanthomonas oryzae pv. oryzae. Mol. Gen. Genet. 261:58-63.

43. Moreau, P., Thoquet, P., Olivier, J., Laterrot, H., and Grimsley, N. 1998. Genetic mapping of $P h-2$, a single locus controlling partial resistance to Phytophthora infestans in tomato. Mol. Plant-Microbe Interact. 11:259-269.

44. Morton, V., and Staub, T. 2008. A short history of fungicides. APSnet Features. Online publication. doi:10.1094/APSnetFeature-2008-0308

45. North Carolina Agricultural Research Service. 2008. Notice of Release of NC 1 CELBR and NC 2 CELBR Tomato Breeding Lines, Raleigh, NC.

46. Nowicki, M., Foolad, M. R., Nowakowska, M., and Kozik, E. 2012. Potato and tomato late blight caused by Phytophthora infestans: an overview of pathology and resistance breeding. Plant Dis. 96:4-17.

47. Pedersen, W. L., and Leath, S. 1988. Pyramiding major genes for resistance to maintain residual effects. Annu. Rev. Phytopathol. 26:369-378.

48. Peralta, I. E., Knapp, S., Spooner, D. M. 2008. Taxonomy of Wild Tomatoes and Their Relatives (Solanum sect. Lycopersicoides, sect. Juglandifolia, sect. Lycopersicon; Solanaceae). American Society of Plant Taxonomists, Ann Arbor, MI

49. Ranc, N., Muños, S., Santoni, S., and Causse, M. 2008. A clarified position for Solanum lycopersicum var. cerasiforme in the evolutionary history of tomatoes (Solanaceae). BMC Plant Biol. 8:130-147.

50. Richards, M. C., Raymond, W., and Barratt, A. 1946. Partial survey of the genus Lycopersicon for resistance to Phytophthora infestans. Plant Dis. Rep. 30:16-20.

51. Ristaino, J. B. 2010. The 2009 potato and tomato late blight epidemics: genealogical history, multiple sources and migration events. (Abstr.) Phytopathology 100:S161.

52. Rutgers. 2013. Wapsipinicon Peach: Tomato Varieties. New Jersey Agricultural Experiment Station, New Brunswick.

53. Seidl, A. C., and Gevens, A. J. 2013. Characterization and distribution of three new clonal lineages of Phytophthora infestans causing late blight in Wisconsin from 2009 to 2012. Am. J. Potato Res. 90:551-560.

54. Shattock, R. C. 1988. Studies on the inheritance of resistance to metalaxyl in Phytophthora infestans. Plant Pathol. 37:4-11.

55. Stevenson, W., James, R., Inglis, D., Johnson, D., Schotzko, R., and Thornton, R. 2007. Fungicide spray programs for defender, a new potato cultivar with resistance to late blight and early blight. Plant Dis. 91:13271336.

56. Stevenson, W. R. 1983. An integrated program for managing potato late blight. Plant Dis. 67:1047-1048.

57. Stevenson, W. R., Loria, R., Franc, G. D., and Weingartner, D. P. 2001 Compendium of Potato Diseases. American Phytopathological Society, St Paul, MN.

58. Stewart, H. E., Bradshaw, J. E., and Pande, B. 2003. The effect of the presence of $R$-genes for resistance to late blight (Phytophthora infestans) of potato (Solanum tuberosum) on the underlying level of field resistance. Plant Pathol. 52:193-198.

59. Vleeshouwers, V. G. A. A., van Dooijeweert, W., Keizer, L. C. P., Kijpkes, L., Grovers, F., and Colon, L. T. 1999. A laboratory assay for Phytophthora infestans resistance in various Solanum species reflects the field situation. Eur. J. Plant Pathol. 105:241-250. 